\title{
24. LATE PLEISTOCENE UPWELLING AND PRODUCTIVITY VARIATIONS IN THE NORTHWEST INDIAN OCEAN DEDUCED FROM SPECTRAL ANALYSES OF GEOCHEMICAL DATA FROM SITES 722 AND $724^{1}$
}

\author{
Graham P. Weedon ${ }^{2}$ and Graham B. Shimmield ${ }^{3}$
}

\begin{abstract}
The Oman Margin and Owen Ridge underlie a seasonal upwelling system driven by the Southwest Monsoon. Variations in sediment composition partly reflect changes in the intensity of upwelling and productivity. Samples spanning the last 350 k.y. were obtained from ODP Site 724 on the Oman Margin and Site 722 on the Owen Ridge. Inorganic geochemical time series were investigated with spectral and cross-spectral techniques in order to investigate the long-term variability of the upwelling system.

The Oman Margin records show no strongly cyclic patterns, probably due to bioturbation and the input of fluvial material. Conversely, the Owen Ridge records are strongly cyclic being composed predominantly of pelagic carbonate and wind-blown terrigenous material. The Ridge records have permitted reconstruction of the upwelling history.

The amount of calcium carbonate on the Owen Ridge varies at three of the Milankovitch orbital periods (100, 41, and 23 k.y.) and is coherent and in phase with global ice volumes. Maximum accumulation rates of wind-blown terrigenous material are inversely related to carbonate contents. The flux of terrigenous material is probably determined by continental aridity. Thus, minimum carbonate contents correspond to maximum aridity and glacial conditions.

Other studies (this volume) have demonstrated that wind velocity controls the sorting and grain size of the terrigenous material deposited on the ridge. Wind velocities vary at the three orbital periods, with the $23 \mathrm{k} . \mathrm{y}$. orbital precession period dominant, reflecting the direct link between orbital insolation patterns and regional atmospheric pressure (i.e., global ice volumes are not considered as important). The proportions of heavy minerals in the non-carbonate fraction are recorded by $\mathrm{Ti} / \mathrm{Al}$ and $\mathrm{Cr} / \mathrm{Al}$. These parameters vary at the three orbital periods, and are dominated by $23 \mathrm{k} . \mathrm{y}$. forcing, suggesting that the amount of heavy minerals transported to the Ridge is controlled by wind speed. However, maximum heavy mineral contents are in phase with maximum terrigenous flux rather than maximum grain size. This suggests that aridity determines the timing of heavy mineral transport. Because the heavy minerals are coarser and denser than average grains, the proportion making up the wind-blown sediment depends on the wind speed during arid periods.

Wind velocity also influences upwelling intensity, yet ocean productivity records $(\mathrm{Ba} / \mathrm{Al}, \mathrm{P} / \mathrm{Al}, \mathrm{Ni} / \mathrm{Al})$ are dominated by $100 \mathrm{k} . \mathrm{y}$. cycles, rather than the $23 \mathrm{k} . \mathrm{y}$. precession periodicity, suggesting an indirect link with global ice volumes. Productivity records are coherent with carbonate, but not ice volumes at the $23 \mathrm{k} . y$. period. Additionally, productivity and $\% \mathrm{CaCO}_{3}$ are in phase at the 100 and 41 k.y. periods. We suggest that at these frequencies, productivity is related to the supply of nutrients from continental runoff and hence aridity. At the $23 \mathrm{k}$.y. period, productivity variations lagged $\% \mathrm{CaCO}_{3}$ by about $40^{\circ}$ suggesting that as well as runoff there was another, delayed source of nutrients, possibly intermediate water upwelled by the effect of the Southwest Monsoon.
\end{abstract}

\section{INTRODUCTION}

This study is based on two sets of inorganic geochemical time series derived from samples obtained during Leg 117 of the Ocean Drilling Program. The sites are located on the Owen Ridge (Site 722 at $2028 \mathrm{~m}$ water depth) and Oman Margin (Site 724 at $593 \mathrm{~m}$ water depth) (Fig. 1) and underlie an area of upwelling driven by the summer monsoon. The composition of the sediments in this region have varied in relation to the upwelling and productivity of the area (Prell, 1984; Prell, Niitsuma, et al., 1989). We attempt here to investigate and explain the long-term variations in upwelling and productivity through the use of inorganic geochemical indicators.

The geochemical analyses and the general nature of the time series are discussed by Shimmield and Mowbray (this volume). Although net accumulation rates are approximately twice as high

\footnotetext{
${ }^{1}$ Prell, W. L., Niitsuma, N., et al., 1991. Proc. ODP, Sci. Results, 117: College Station, TX (Ocean Drilling Program).

2 Department of Earth Sciences, University of Cambridge, Downing Street, Cambridge, CB2 3EQ, United Kingdom.

3 Department of Geology and Geophysics, University of Edinburgh, West Mains Road, Edinburgh, EH9 3JW, United Kingdom.
}

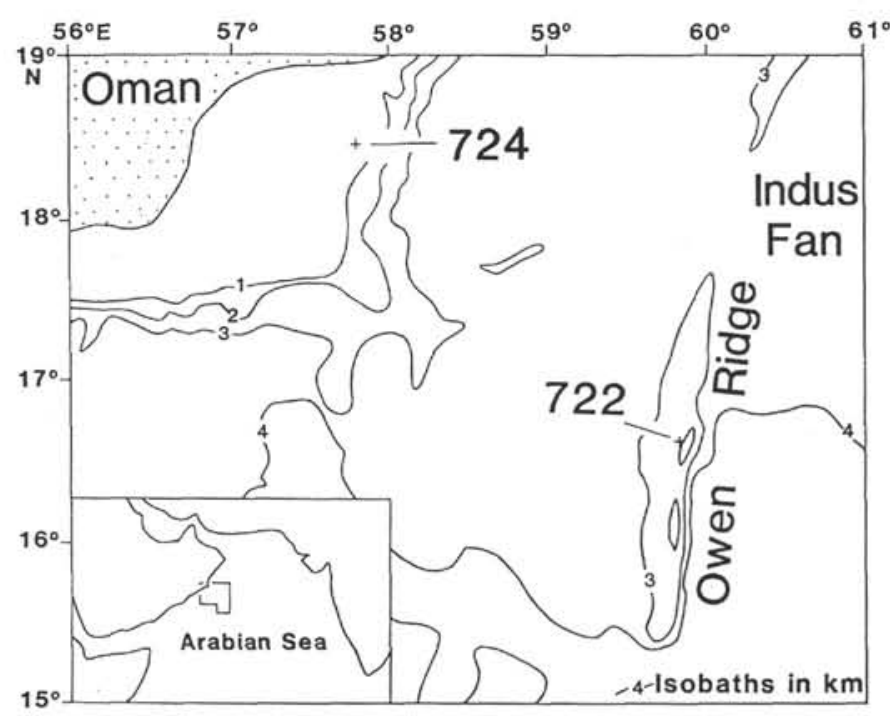

Figure 1. Location map for Sites 722 and 724. 
on the Oman Margin, the two sample sets span the same time interval (6-350 k.y.B.P.) and both contain a similar number of samples. This permits a direct comparison of the time series from the two sites. By using standard spectral and cross-spectral methods, we attempt to interpret the relationships between various geochemical parameters at each site interpreted as proxy indicators of different paleoceanographic phenomena. This enables us to use the relationship between the time series to describe the relationship between separate environmental factors.

Both sites in this study underlie the Oman upwelling system which is driven seasonally by the Southwest Monsoon. The upwelling influences, via surface productivity variations, the supply of biogenic calcium carbonate, biogenic silica, and organic matter to the seafloor. This combined with input of fluvial and eolian detrital material from the land, water column oxygenation levels (probably partially related to upwelling intensity), and diagenesis, determine the composition of the sediment (Prell, Niitsuma, et al., 1989). Thus, long-term variations in upwelling, and hence monsoon intensity, may be recorded by variations in sediment geochemical composition. Prell (1984) demonstrated that the percentage of $G$. bulloides, thought to reflect sea surface temperature and thus upwelling intensity, displays fluctuations which are highly coherent with global ice volume variations at the period of orbital precession $(23 \mathrm{k} . \mathrm{y}$.). His record was too short to investigate relationships at the longer orbital periods. Nevertheless he demonstrated that changes in upwelling occur over long periods. Our records of sediment composition will allow us to identify and investigate long-period variations in the nature of the Oman upwelling system.

We have compared each time series with the SPECMAP oxygen isotope curve of Imbrie et al. (1984). Scaled in standard deviation units this curve provides an approximate measure of global ice volume. We have used the negative stack so that positive values correspond to interglacial conditions. It has been demonstrated that global ice volumes are closely related to the Earth's orbital variations (Imbrie et al., 1984). However, ice volume fluctuations show a time lag behind orbital variations of about a quarter of a cycle (i.e., $90^{\circ}$ or about $5 \mathrm{k}$.y. for the precession cycle). Thus comparison of our time series with the SPECMAP curve allows us to assess the relationship between upwelling and global ice volume variations and to assess indirectly the relationship between upwelling and orbital variations.

\section{THE GEOCHEMICAL DATA AS PROXY-PALEOCEANOGRAPHIC RECORDS}

The various geochemical parameters used in this study serve as proxy-paleoceanographic records (Figs. 2 and 3). They are treated in groups according to the type of oceanographic signal they represent based on the assessment of Shimmield and Mowbray (this volume). The groups are: (1) terrigenous input records (i.e., $\left.100 \%-\% \mathrm{CaCO}_{3}\right)$; $(2)$ heavy mineral records $(\mathrm{Ti} /$ $\mathrm{Al}$ and $\mathrm{Cr} / \mathrm{Al})$; (3) productivity records $(\mathrm{Ba} / \mathrm{Al}, \mathrm{P} / \mathrm{Al}$ and $\mathrm{Ni} /$ $\mathrm{Al})$; (4) sediment/bottom water redox state record ( $\mathrm{Cu} / \mathrm{Al})$; and (5) silicon records $(\mathrm{Si} / \mathrm{Al})$.

Induced correlations between the measured concentrations of the non-carbonate elements may occur simply due to variations in calcium carbonate content. To remove induced correlations we have normalized our measurements to the concentration of aluminum (Shimmield and Mowbray, this volume). This method relies on the fact that aluminum is restricted to clay minerals. These ratios provide a monitor of changes in the composition of the non-carbonate fraction.

It is shown by Shimmield and Mowbray (this volume) that $\mathrm{CaCO}_{3}$ is inversely correlated with mass accumulation rate. Thus the mass accumulation rate depends primarily on the input of terrigenous siliciclastics. For the spectral and cross spectral analyses we have used the carbonate contents actually measured, as this provides a mirror image of the percentage of terrigenous components $\left(100 \%-\% \mathrm{CaCO}_{3}\right)$. Thus the variance and coherency spectra for $\% \mathrm{CaCO}_{3}$ are identical to those of terrigenous material whereas the phase values for the carbonate record are increased by $180^{\circ}$. On the Owen Ridge (including Site 722), given its distance from land and elevation above the seafloor, most terrigenous material is probably derived by wind transport from the Arabian Peninsular (Sirocko and Sarnthein, 1990; Clemens and Prell, 1990; Clemens and Prell, this volume). Conversely on the Oman Margin (including Site 724) fluvial processes and bottom currents on the shelf probably control the rate and type of sediment accumulating (Shimmield et al. 1990).

Titanium and chromium reside in heavy minerals so the variation in $\mathrm{Ti} / \mathrm{Al}$ and $\mathrm{Cr} / \mathrm{Al}$ indicates the proportion of heavy minerals in the non-carbonate fraction (Shimmield and Mowbray, this volume). Spears and Kanaris-Sotiriou (1976) and Boyle (1983) demonstrated that heavy minerals occur preferentially within coarser sediments. They used the $\mathrm{Ti} / \mathrm{Al}$ ratio as a measure of sorting and grain size in sediments when contamination from underlying basaltic material is not a problem. On the Owen Ridge where the terrigenous material is wind-blown, sorting and grain size (and thus $\mathrm{Ti} / \mathrm{Al}$ and $\mathrm{Cr} / \mathrm{Al}$ ) is probably a function of wind velocity.

Shimmield and Mowbray (this volume) argued that $\mathrm{Ba} / \mathrm{Al}$ is related to productivity, although the causal connection has yet to be established. P/Al also appears to be linked to productivity as phosphorus increases with the organic matter content in the sediment. However, the distribution of phosphorus is complicated by its occurrence on the Oman Margin within phosphatic nodules (Prell, Niitsuma, et al., 1989). Ni/Al variations appear to be related to organic matter complexation in the water column and thus act as another proxy for surface productivity. $\mathrm{Cu} /$ Al variations, however, apparently depend on the redox state of the water column and interfacial sediment-which is probably determined by the flux of organic matter and the relative position of the oxygen minimum zone.

Silicon concentrations in these sediments are mainly determined by the amount of biogenic opal preserved, the amount of quartz derived from land and, to a minor extent, the proportion of clay minerals. Although the $\mathrm{Si} / \mathrm{Al}$ ratio is determined by a variety of factors, it is possible that one factor outweighs the others producing a useful proxy-record.

\section{TIME SERIES AND SPECTRAL METHODS}

The time scales adopted for the Site 722 and 724 geochemical data were derived from the planktonic foraminiferal oxygen isotope determinations of Clemens and Prell (this volume) and Zahn and Pedersen (this volume), respectively. In both cases they matched key variations in their measured $\delta^{18} \mathrm{O}$ to the SPECMAP isotopic time scale of Imbrie et al. (1984). Their dated tie points were then used to generate linearly interpolated ages for each sample used in this study. The sample interval was $10 \mathrm{~cm}$ in Hole 722B with 146 samples spanning the interval 6-365 k.y.B.P. In Hole $724 \mathrm{C}$ the sample interval was $20 \mathrm{~cm}$ and we collected 156 samples spanning 6-357 k.y. B.P. These data are illustrated in Figures 2 and 3. To produce time-series with values equally spaced in time we used a Gaussian interpolation program provided by N. J. Shackleton (Cambridge, U.K.). This method weights the values over a specified data window and calculates an interpolation value if sufficient data are available. For both sets of data, and the SPECMAP isotope variations of Imbrie et al. (1984), the interpolation window was set at 7.4 k.y. wide with an interpolation interval of 2.5 k.y. started from 6.0 k.y.B.P.

The variance-, coherency-, and phase-spectra were calculated according to the standard Blackman-Tukey Fourier spectral methods described by Jenkins and Watts (1968). An up-to-date introduction to spectral analysis is provided by Priestley (1981). The 


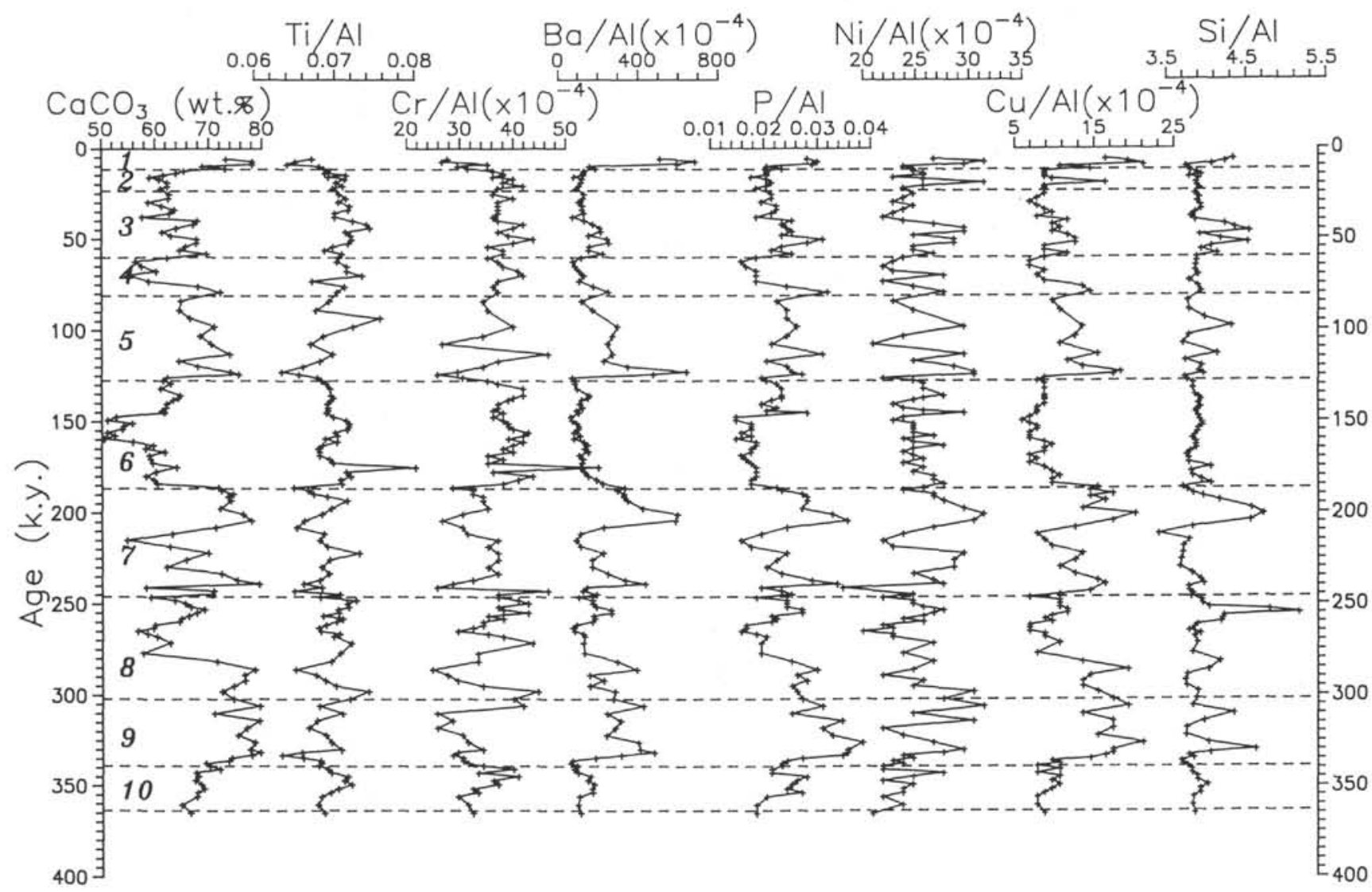

Figure 2. Geochemical data for Hole 722B. The time scale is based on within-hole oxygen isotope values correlated with the SPECMAP time scale (Clemens and Prell, this volume). Standard isotopic stage numbers are indicated (Imbrie et al. 1984).

time series were linearly detrended before spectral analysis. For every time series the number of lags used was 47 , or about one third the number of interpolated values (145 values for Hole $722 \mathrm{~B}$ and 142 values for Hole $724 \mathrm{C}$ ). Where time series of one geochemical parameter were compared for the two sites we used the interval from 6-357 k.y. in both cases.

Variance spectra are used to identify the dominant periods of variation in a time series as indicated by major spectral peaks. The bandwidth or frequency resolution of the various spectra is indicated by a horizontal bar in each case. The mean variance density of each time series is controlled by the average absolute amplitude of the time series. The absolute amplitudes of the time series in this study vary by orders of magnitude (Figs. 2 and 3) so it is difficult to compare spectra plotted on a linear variance density scale. Rather than use a log scale we have divided each variance density spectrum by the sum of its variance density. This allows direct comparison of relative variance density without affecting the shape of the spectra.

Coherency spectra indicate the degree of linear correlation of the amplitudes of two time series at particular frequencies of variation. Some authors alternatively refer to "coherence" (coherency squared) which denotes the degree of correlation of the variances of two time series at different frequencies (Priestley, 1981). Coherency spectra are often plotted on a hyperbolic arctangent scale so that a single confidence interval can be plotted which applies to all estimates. Here we have simply plotted estimated coherency against frequency and point out that the variance of the estimates decreases with increasing coherency. Although higher coherency indicates higher correlation, the significance of the correlation is determined by the confidence level which is exceeded in each case. Here we have indicated the $80 \%$ confidence levels.
Phase spectra describe the relative timing of variations in two time series. Although phase estimates are generated for the same range of frequencies as the coherency spectra, the phase estimates are only significant where coherency is significant. On the phase spectra illustrated, negative phase values indicate that the first named parameter lags (or follows variations in) the second. The errors associated with the phase estimates are quoted in the tables of cross-spectral results.

\section{OWEN RIDGE DATA-SPECTRAL RESULTS}

\section{Terrigenous Input Records}

The variations in $\% \mathrm{CaCO}_{3}$ act as an inverse measure of the variations in the amount of terrigenous material accumulating on the Owen Ridge (Shimmield and Mowbray, this volume; Clemens and Prell, this volume). These variations are dominated by 100 k.y. cycles with some concentration of variance at the 41 and 23 k.y. periods (Fig. 4A). These periods of variation are matched by the orbital-climatic or Milankovitch cycles present in the proxy-global ice volume curve (the SPECMAP $\delta^{18} \mathrm{O}$ variations). The absence of a spectral peak related to the 19 k.y. precession cycle is due to the weak contribution of this period to orbital changes over the last 350 k.y. (Imbrie et al., 1984). At all three Milankovitch periods, variations in $\% \mathrm{CaCO}_{3}$ are coherent and in phase (Table 1) with the ice volume variations-suggesting some environmental link between the supply of terrigenous material $\left(100 \%-\% \mathrm{CaCO}_{3}\right)$ and ice volume or glacial boundary conditions. The carbonate spectrum also has peaks related to variations with periods of 16 and $12 \mathrm{k}$.y. (Fig. 4A). These peaks may be related to the other peaks as a combination tone $(1 / 23$ $+1 / 41=1 / 15)$ and harmonic $(23 / 2=12)$, respectively, suggesting a non-linear response of carbonate contents to climatic 


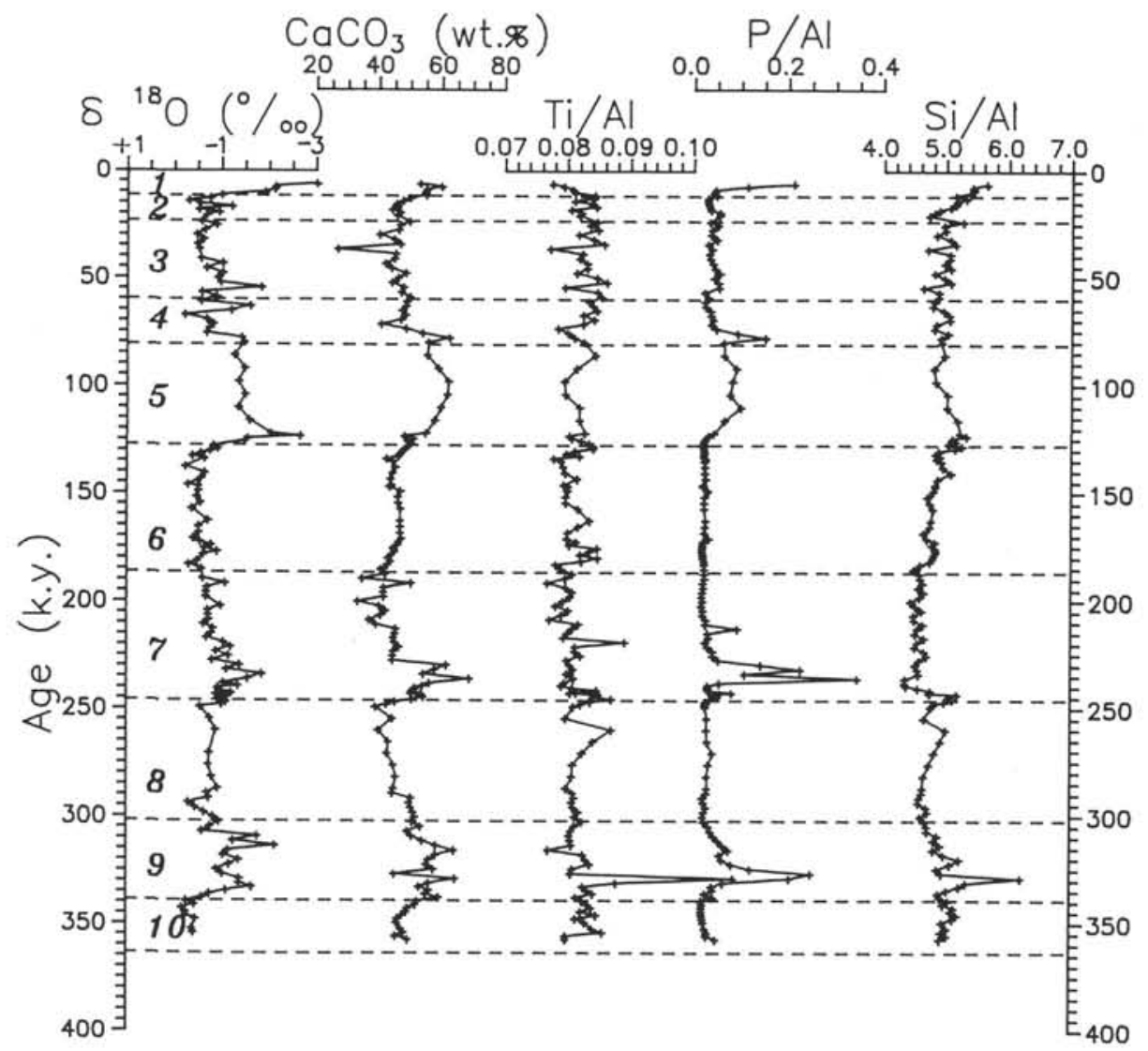

Figure 3. Geochemical data for Hole 724C. Time scale based on oxygen isotope values correlated with SPECMAP time scale (Zahn and Pedersen, this volume).

variations. The relationship between carbonate and $\mathrm{Ba} / \mathrm{Al}$ records (Fig. 4B) is discussed below.

\section{Heavy Mineral (Wind Velocity) Records}

Both the $\mathrm{Cr} / \mathrm{Al}$ and $\mathrm{Ti} / \mathrm{Al}$ records produce spectral peaks at the three Milankovitch periods but, unlike the ice volume and carbonate records, the 23 k.y. peak is dominant (Fig. 5A). Both records are coherent with each other at all three periods confirming that they are both controlled by the same environmental process. Given the errors, the slight difference in phase of these records does not appear to be significant (Table 1). The $\mathrm{Cr} / \mathrm{Al}$ ratio is only just coherent with ice volume at the three orbital periods whereas $\mathrm{Ti} / \mathrm{Al}$ is coherent only at the 100 and $41 \mathrm{k} . \mathrm{y}$. periods (Figs. 5C and 5D). However, heavy mineral concentrations are highly coherent at all three orbital frequencies with $\% \mathrm{CaCO}_{3}$ and differ in phase by about $180^{\circ}$ (Fig. 5B).

\section{Productivity Records}

$\mathrm{Ba} / \mathrm{Al}, \mathrm{Ni} / \mathrm{Al}$, and $\mathrm{P} / \mathrm{Al}$ spectra are all dominated by 100 k.y. peaks and are highly coherent and in phase with each other (Figs. 6A and 6B). The high coherency, phase, and spectral structure of these records supports the suggestion that they are all closely linked to productivity. Despite a similarity in spectral shape, these records are only coherent with the proxy-ice volume record at the 100 and 41 k.y. periods (Fig. $6 \mathrm{C}$ ). At these coherent periods, $\mathrm{Ba} / \mathrm{Al}$ and ice volumes are in phase; productivity was highest at the height of interglacials. Productivity and heavy mineral records are also coherent only at the 100 and 41 k.y. periods (Fig. 6D). However, productivity is highly coherent at all three orbital periods with $\% \mathrm{CaCO}_{3}$ (Fig. 4B). At the 100 and $41 \mathrm{k} . \mathrm{y}$. frequencies carbonate content and productivity are essentially in phase (Table 1). At the 23 k.y. frequency Ba/Al-indicated productivity lags carbonate, and thus also interglacials, by about $40^{\circ}$ (Fig. 4B).

\section{Bottom-water Redox State Record}

The $\mathrm{Cu} / \mathrm{Al}$ record has a similar spectrum to the productivity records. Additionally, this record has very high coherency and identical phase with them over a wide range of frequencies (Fig. 7A). This confirms that the redox state of the bottom waters and sediment was directly related to productivity via changes in organic matter flux as suggested by Shimmield and Mowbray (this volume). As for the productivity records, $\mathrm{Cu} / \mathrm{Al}$ is only coherent with ice volume variations at the 100 and $41 \mathrm{k} . \mathrm{y}$. periods (Fig. 7B).

\section{Silicon Record}

The $\mathrm{Si} / \mathrm{Al}$ variations appear to be dominated by cycles of about 56 k.y. with no spectral peaks that are coincident with peaks from other records (Figs. 8A-8D). This period of variation has been recognized elsewhere (S. Clemens, pers. comm., 1989), but its origin remains unclear. The small $26 \mathrm{k} . \mathrm{y}$. peak of the $\mathrm{Si} / \mathrm{Al}$ spectrum partially represents the second harmonic of the 56 k.y. variations given the frequency ratio between the two and the asymmetric shape of the $\mathrm{Si} / \mathrm{Al}$ time series. However, although this peak is not quite coincident with the precession peak, there is high coherency between this record and both the heavy mineral and productivity records at this period.

\section{OWEN RIDGE DATA-INTERPRETATION}

The preceding sections have demonstrated that fluctuations in most geochemical factors are indirectly related to the orbital- 

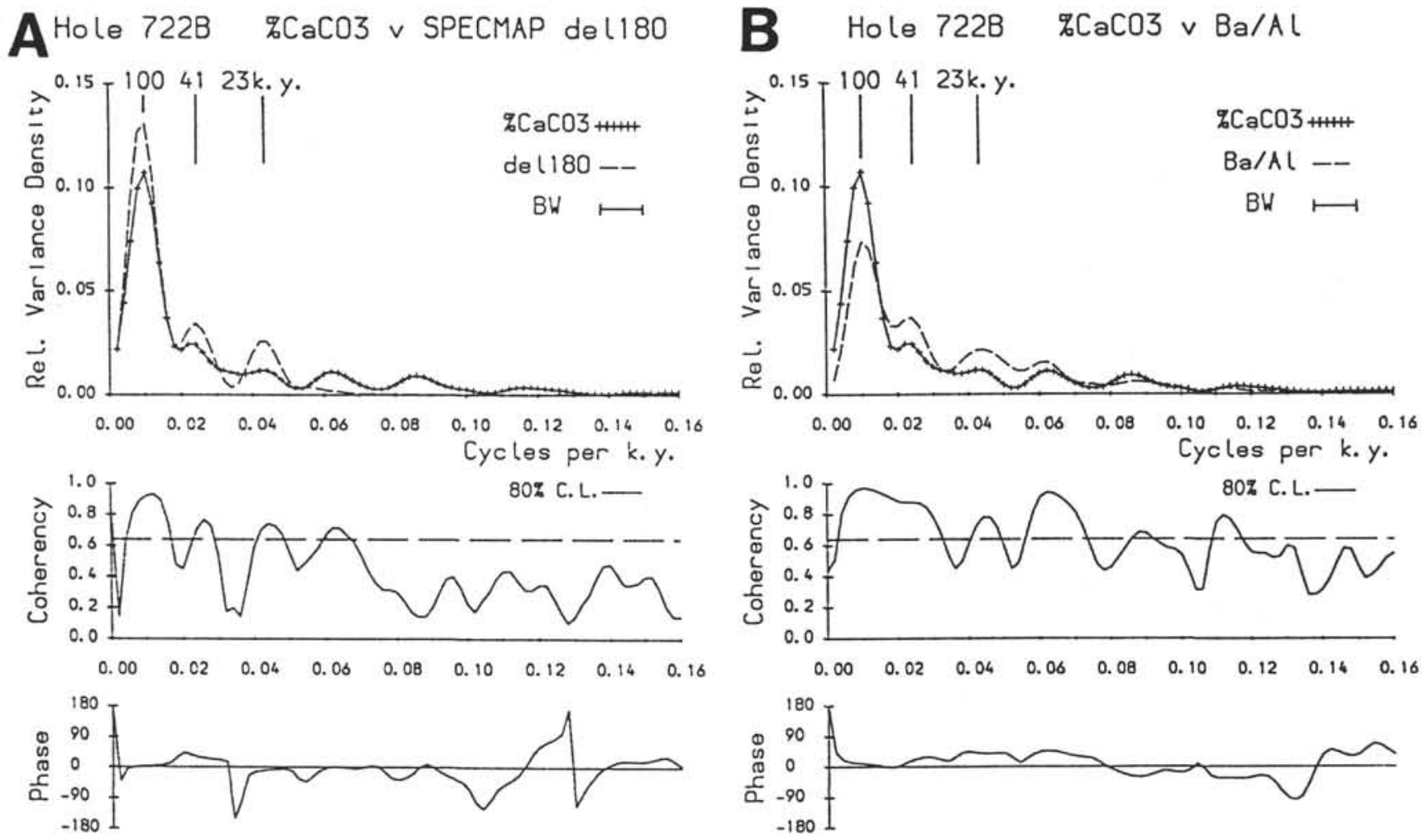

Figure 4. Variance and cross spectra comparing $\% \mathrm{CaCO}_{3}$ time series from Hole $722 \mathrm{~B}$ with SPECMAP oxygen isotope variations (A) and with $\mathrm{Ba} / \mathrm{Al}(\mathrm{B})$. Variance spectra are plotted using relative variance density (variance density/total variance density). The bandwidths of the spectra are indicated by BW. Note that coherency is plotted on a linear, not a hyperbolic arc tangent, scale. Positive phase indicates that the first named parameter (here $\% \mathrm{CaCO}_{3}$ ) leads variations in the second.

climatic cycles. However, the variety of shapes associated with the variance spectra, and the differing coherencies and phases, suggest different environmental processes link the various geochemical records to the orbital variations.

According to previous studies variations in the Southwest Monsoon wind speed, as indicated by pollen- and grain sizespectra, are dominated by the $23 \mathrm{k}$.y. orbital precession and not the 100 k.y. eccentricity cycle (Rossignol-Strick, 1983; Prell and Van Campo, 1986; Clemens and Prell, 1990). This reflects the control on the monsoon wind strength by regional insolation patterns-though ice volumes and glacial stage boundary conditions in general (ice volume, sea level, albedo, etc.) have been shown to be important (Prell end Kutzbach 1987). Clemens and Prell (1990) demonstrated that at the 23 k.y. period, minimum ice volumes (interglacials) and the wettest terrestrial conditions lag maximum insolation by about $70^{\circ}$ or $4.5 \mathrm{k}$.y. This lag is attributable to delays in ice sheet growth and melting. An additional lag of $70^{\circ}$ was noted between minimum ice volumes and maximum wind strength, as recorded by the grain size of the terrigenous fraction. They explain this further lag as resulting from the effect of latent heat transport from the southern Indian Ocean on the development of the monsoon. The relationship of oceanic productivity to this model of the monsoon is investigated below.

Variations in $\% \mathrm{CaCO}_{3}$ are dominated by the 100 k.y. cycle and are coherent and in phase with ice volumes at all three orbital periods. Aridity seems to have determined the flux of windblown material to the Owen Ridge (Clemens and Prell, 1990). As mass accumulation rates of the wind-blown terrigenous material are inversely related to carbonate contents, the $\% \mathrm{CaCO}_{3}$ record can be used as a proxy for aridity (low carbonate corresponds to high aridity and glacial periods).
The heavy mineral records ( $\mathrm{Ti} / \mathrm{Al}$ and $\mathrm{Cr} / \mathrm{Al}$ ) are dominated by 23 k.y. rather than 100 k.y. variations suggesting a link between the amount of heavy minerals and wind strength (Fig. $5 \mathrm{~A})$. There is no coherency between heavy mineral concentration and ice volumes at the $23 \mathrm{k}$.y. period, but there is significant coherency with the $\% \mathrm{CaCO}_{3}$ record at all three orbital periods (Figs. 5B and 5C). Furthermore, the phase relationship indicates that minimum carbonate and thus maximum aridity corresponds to maximum heavy mineral concentrations. If wind strength were the sole control on heavy mineral transport, $\mathrm{Ti} / \mathrm{Al}$ should lag $\% \mathrm{CaCO}_{3}$ or minimum ice volumes by just $70^{\circ}$ rather than the observed $168^{\circ}$ considering the Clemens and Prell (1990) grain size data. To reconcile these observations we suggest that the timing or phase of heavy mineral transport was controlled by continental aridity and the availability of dust. However, since the heavy minerals were both concentrated in the coarser dust fraction and are denser than most grains, the proportion transported would have been governed by wind strength rather than the availability of dust.

Since the degree of upwelling of nutrient-rich water off Oman depends on the strength of the monsoon wind (Prell, 1984), one might expect that the productivity record would be dominated by $23 \mathrm{k} . \mathrm{y}$. variations. Instead productivity variations as indicated by $\mathrm{Ba} / \mathrm{Al}, \mathrm{Ni} / \mathrm{Al}$, and $\mathrm{P} / \mathrm{Al}$ are dominated by the $100 \mathrm{k} . \mathrm{y}$. orbital cycles (Figs. 6A and 6B). The dominance of this cycle possibly indicates that global ice volume indirectly determines the degree of productivity. There is partial support for this hypothesis as ice volumes are coherent at the 100 and 41 k.y. periods, though there is no significant coherency at the 23 k.y. period. However, productivity is highly coherent with $\% \mathrm{CaCO}_{3}$ (aridity) at all three orbital periods. Additionally, at the longer periods carbonate contents and productivity are in phase, and 
Table 1. Cross spectral results from Hole 722B. Significant coherency values $(80 \%$ level) exceed 0.64 .

\begin{tabular}{|c|c|c|c|}
\hline Parameters & Period/k.y & Coherency & Phase/degrees \\
\hline \multirow[t]{3}{*}{$\% \mathrm{CaCO}_{3}$ v SPECMAP $\delta^{18} \mathrm{O}$} & 100 & 0.92 & $+4^{\circ} \pm 18^{\circ}$ \\
\hline & 41 & 0.71 & $+30^{\circ} \pm 34^{\circ}$ \\
\hline & 23 & 0.74 & $-9^{\circ} \pm 31^{\circ}$ \\
\hline \multirow[t]{3}{*}{$\% \mathrm{CaCO} 3 \vee \mathrm{Ba} / \mathrm{Al}$} & 100 & 0.97 & $+10^{\circ} \pm 14^{\circ}$ \\
\hline & 41 & 0.88 & $+21^{\circ} \pm 21^{\circ}$ \\
\hline & 23 & 0.78 & $+39^{\circ} \pm 29^{\circ}$ \\
\hline \multirow[t]{3}{*}{$\mathrm{Ti} / \mathrm{Al} \vee \mathrm{Cr} / \mathrm{Al}$} & 100 & 0.85 & $+15^{\circ} \pm 23^{\circ}$ \\
\hline & 41 & 0.84 & $+33^{\circ} \pm 24^{\circ}$ \\
\hline & 23 & 0.88 & $-20^{\circ} \pm 21^{\circ}$ \\
\hline \multirow[t]{3}{*}{$\mathrm{Ti} / \mathrm{Al}$ $\% \mathrm{CaCO}_{3}$} & 100 & 0.81 & $-152^{\circ} \pm 26^{\circ}$ \\
\hline & 41 & 0.74 & $+175^{\circ} \pm 31^{\circ}$ \\
\hline & 23 & 0.79 & $-168^{\circ} \pm 28^{\circ}$ \\
\hline \multirow{3}{*}{$\mathrm{Ti} / \mathrm{Al}$ SPECMAP $\delta^{18} \mathrm{O}$} & 100 & 0.91 & $-143^{\circ} \pm 19^{\circ}$ \\
\hline & 41 & 0.79 & $-170^{\circ} \pm 28^{\circ}$ \\
\hline & 23 & 0.57 & $+168^{\circ} \pm 44^{\circ}$ \\
\hline \multirow[t]{3}{*}{$\mathrm{Cr} / \mathrm{Al}$ v SPECMAP $\delta^{18} \mathrm{O}$} & 100 & 0.71 & $-167^{\circ} \pm 34^{\circ}$ \\
\hline & 41 & 0.67 & $+150^{\circ} \pm 37^{\circ}$ \\
\hline & 23 & 0.68 & $-149^{\circ} \pm 36^{\circ}$ \\
\hline \multirow[t]{3}{*}{$\mathrm{Ba} / \mathrm{Al} \vee \mathrm{Ni} / \mathrm{Al}$} & 100 & 0.93 & $-8^{\circ} \pm 17^{\circ}$ \\
\hline & 41 & 0.87 & $-1^{\circ} \pm 22^{\circ}$ \\
\hline & 23 & 0.77 & $+20^{\circ} \pm 29^{\circ}$ \\
\hline \multirow[t]{3}{*}{$\mathrm{Ba} / \mathrm{Al} \vee \mathrm{P} / \mathrm{Al}$} & 100 & 0.92 & $-19^{\circ} \pm 18^{\circ}$ \\
\hline & 41 & 0.91 & $-1^{\circ} \pm 19^{\circ}$ \\
\hline & 23 & 0.93 & $+3^{\circ} \pm 17^{\circ}$ \\
\hline \multirow{3}{*}{$\mathrm{Ba} / \mathrm{Al} \vee \operatorname{SPECMAP} \delta^{18} \mathrm{O}$} & 100 & 0.91 & $-2^{\circ} \pm 19^{\circ}$ \\
\hline & 41 & 0.71 & $-7^{\circ} \pm 34^{\circ}$ \\
\hline & 23 & 0.62 & $-23^{\circ} \pm 40^{\circ}$ \\
\hline \multirow[t]{3}{*}{$\mathrm{Ba} / \mathrm{Al}$ × $\mathrm{Ti} / \mathrm{Al}$} & 100 & 0.83 & $+145^{\circ} \pm 25^{\circ}$ \\
\hline & 41 & 0.86 & $+149^{\circ} \pm 22^{\circ}$ \\
\hline & 23 & 0.62 & $+105^{\circ} \pm 40^{\circ}$ \\
\hline \multirow[t]{3}{*}{$\mathrm{Cu} / \mathrm{Al} \vee \mathrm{Ba} / \mathrm{Al}$} & 100 & 0.96 & $+0^{\circ} \pm 15^{\circ}$ \\
\hline & 41 & 0.95 & $-4^{\circ} \pm 16^{\circ}$ \\
\hline & 23 & 0.98 & $+3^{\circ} \pm 13^{\circ}$ \\
\hline \multirow[t]{3}{*}{$\mathrm{Cu} / \mathrm{Al}$ v SPECMAP $\delta^{18} \mathrm{O}$} & 100 & 0.88 & $-4^{\circ} \pm 21^{\circ}$ \\
\hline & 41 & 0.71 & $+0^{\circ} \pm 34^{\circ}$ \\
\hline & 23 & 0.55 & $-17^{\circ} \pm 46^{\circ}$ \\
\hline \multirow[t]{3}{*}{$\mathrm{Si} / \mathrm{Al}$ SPECMAP $\delta^{18} \mathrm{O}$} & 100 & 0.28 & $-79^{\circ} \pm 66^{\circ}$ \\
\hline & 41 & 0.39 & $+6^{\circ} \pm 58^{\circ}$ \\
\hline & 23 & 0.41 & $-56^{\circ} \pm 56^{\circ}$ \\
\hline \multirow[t]{3}{*}{ 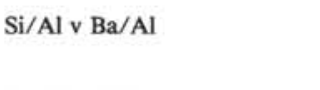 } & 100 & 0.33 & $-30^{\circ} \pm 62^{\circ}$ \\
\hline & 41 & 0.82 & $+22^{\circ} \pm 25^{\circ}$ \\
\hline & 23 & 0.79 & $-19^{\circ} \pm 28^{\circ}$ \\
\hline \multirow[t]{3}{*}{$\mathrm{Si} / \mathrm{Al} \vee \mathrm{Ti} / \mathrm{Al}$} & 100 & 0.39 & $+64^{\circ} \pm 58^{\circ}$ \\
\hline & 41 & 0.61 & $+163^{\circ} \pm 41^{\circ}$ \\
\hline & 23 & 0.79 & $+70^{\circ} \pm 28^{\circ}$ \\
\hline \multirow[t]{3}{*}{$\mathrm{Si} / \mathrm{Al} \vee \% \mathrm{CaCO}_{3}$} & 100 & 0.32 & $-61^{\circ} \pm 63^{\circ}$ \\
\hline & 41 & 0.75 & $+12^{\circ} \pm 31^{\circ}$ \\
\hline & 23 & 0.57 & $-83^{\circ} \pm 44^{\circ}$ \\
\hline
\end{tabular}

at the $23 \mathrm{k} . \mathrm{y}$. frequency carbonate leads productivity by about $40^{\circ}$ (Table 1).

We consider two, not necessarily mutually exclusive, processes to explain the relationship of the productivity records to the other climatic indicators. Both processes involve controls on the nutrient levels in the Arabian Sea acting in concert with the wind-driven upwelling control (Prell, 1984). The first process involves global circulation of bottom waters and the second continental runoff.

Indian Ocean bottom water is mainly derived from Antarctic bottom water which, due to progressive oxidation of organic matter shows a decrease in $\delta^{13} \mathrm{C}$ northward away from the Antarctic (Duplessy et al., 1984). As productivity increased in the interglacials, the increased flux of organic matter to the bottom waters would be expected to cause a decrease in $\delta^{13} \mathrm{C}$. However, $\delta^{13} \mathrm{C}$ actually increased in the northern Indian Ocean bottom water during interglacials indicating an increased flux of Antarctic bottom water (Duplessy and Shackleton, 1985; Kallel et al., 1988). The circulation of bottom waters has been shown to be linked to global, and particularly to northern hemisphere ice volumes (Duplessy and Shackleton, 1985). Upwelling transported nutrients to the surface. However, in this first process, we sug- gest that it was the flux of bottom water to the northern Indian Ocean, influenced by ice volumes, and the mixing of bottomand intermediate-waters, which determined the nutrient levels of the upwelled water and thus surface productivity. This process is unable to explain the lack of coherency and differing phase between the SPECMAP proxy-ice volume record and productivity at the precession period.

The second process, favored here, involves nutrient supply by runoff from the land. Thus low runoff, high aridity, and minimum carbonate contents would correspond to periods of low productivity and vice-versa. This is confirmed by the high coherency between $\mathrm{Ba} / \mathrm{Al}$ and $\% \mathrm{CaCO}_{3}$ at all three frequencies and the coincidence of phase at the 100 and 41 k.y. periods (Fig. 4B). An extra factor is needed to explain why productivity lagged $\% \mathrm{CaCO}_{3}$ by about $40^{\circ}$ or $2.6 \mathrm{k}$.y. at the frequency of the precession cycle. This observation suggests that at this period of variation, as well as nutrients supplied from runoff, an additional, but delayed, supply was important-i.e., upwelled water related to the monsoon winds. In support of this second process we note that a spectrum for the last 300 k.y. of $\%$ G. bulloides (a sea surface temperature indicator) is dominated by $41 \mathrm{k} . \mathrm{y}$., not 100 k.y., variations (Clemens and Prell, 1990). Thus neither wind speed, nor upwelling variations alone, are able to account for the predominantly $100 \mathrm{k} . \mathrm{y}$. variations in productivity reported here.

The silicon record shows a unique style of variation at a 56 k.y. period. The origin of this variation is not known, but as the record is composite, depending on biogenic silica, quartz, and clay mineralogy, its interpretation is not straightforward. Nevertheless, there is coherency at the period of the precession cycle with both the productivity and heavy mineral records (Figs. 8B and $8 \mathrm{C}$ ). This may indicate productivity control on biogenic silica production (Shimmield and Mowbray, this volume) and variations in the proportion of quartz relative to clay related to sorting and wind velocity.

\section{OMAN MARGIN DATA-RESULTS AND INTERPRETATION}

The $\delta^{18} \mathrm{O}$ record of Hole $724 \mathrm{C}$ shows a variance spectrum with a strong 100 k.y. peak, a weak 41 k.y. peak, but no 23 k.y. peak (Fig. 9A). In spite of this coherency is very high with the SPECMAP $\delta^{18} \mathrm{O}$ record at all three periods. We believe the damping of high frequency spectral peaks in the local oxygen isotope and other geochemical records denotes bioturbational smoothing of the variations and perhaps variable sedimentation rates over periods of 1-10 k.y. (Figs. 9 and 10; Table 2; Dalfes et al., 1984).

Data for Hole $724 \mathrm{C}$ is restricted to measurements of $\% \mathrm{CaCO}_{3}$, $\mathrm{Ti} / \mathrm{Al}, \mathrm{P} / \mathrm{Al}$, and $\mathrm{Si} / \mathrm{Al}$. The records from the Oman Margin differ substantially in character to those of the Owen Ridge (Figs. 2 and 3). Both terrigenous input $\left(100 \%-\% \mathrm{CaCO}_{3}\right)$ and productivity records $(\mathrm{P} / \mathrm{Al})$ show 100 k.y. variations which are coherent with each other and the global ice volume variations (Figs. 9B-9D). However, the carbonate records at the ridge and margin sites are only coherent with each other at the 23 k.y. period (Fig. 11A, Table 3). As there is no 23 k.y. spectral peak in the carbonate spectrum for Hole $724 \mathrm{C}$ this coherency is unexpected. A tentative explanation might be that terrigenous input to the margin was dominated by wind-blown dust at the $23 \mathrm{k} . \mathrm{y}$. period and by fluvially-derived material at longer periods.

The $\mathrm{P} / \mathrm{Al}$ values are much greater at the margin than at the Owen Ridge site suggesting greater phosphorus cycling and diagenesis nearer the coast (Figs. 2 and 3). Although sedimentation rates were much higher on the Oman Margin, it was suggested that the occurrence of phosphatic nodules there resulted from episodes of reduced sedimentation rate (Prell, Niitsuma, et al., 1989 , p. 388-390). The Ti/Al record shows no significant spec- 

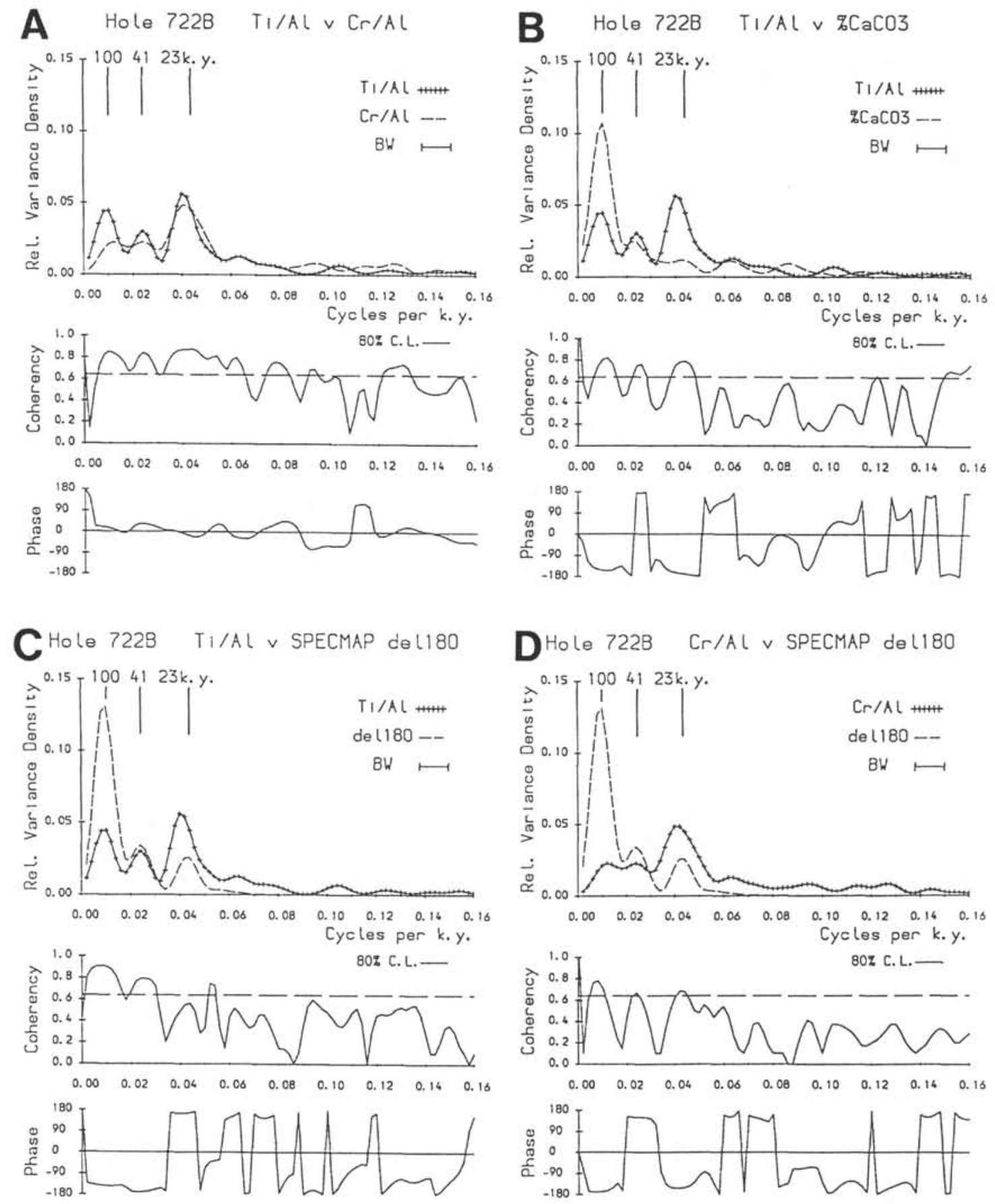

Figure 5. Variance and cross spectra related to heavy mineral/wind velocity $(\mathrm{Ti} / \mathrm{Al}, \mathrm{Cr} / \mathrm{Al})$ records from $\mathrm{Hole} 722 \mathrm{~B}$. See text for discussion.

tral peaks and no coherency with ice volumes (Fig. 10A). There is also no correlation between $\mathrm{Ti} / \mathrm{Al}$ on the margin and the ridge (Fig. $11 \mathrm{C}$ ). As Ti/Al levels are much greater on the margin, we propose that fluvially-derived heavy minerals were deposited there in addition to the wind-blown material found on the ridge.

The variance spectrum of $\mathrm{Si} / \mathrm{Al}$ on the margin is totally different from that of the ridge, with variance concentrated at very low frequencies (Fig. 11D). There are no significant spectral peaks although coherency is high at the $100 \mathrm{k}$.y. period when compared to the ice volume record (Fig. 10B, Table 2). As the
$\mathrm{Si} / \mathrm{Al}$ ratios are much greater on the margin, we again suggest fluvially-derived material explains the difference in the character of the margin and ridge records.

\section{CONCLUSIONS}

The records from the Oman Margin site are dominated by long-period variations with no pronounced short-period regular cyclicity probably due to intense bioturbation and perhaps shortterm variable sedimentation rates related to the input of fluvial material. Conversely, the Owen Ridge site records are strongly cyclic and dominated by pelagic and wind-blown material. The 

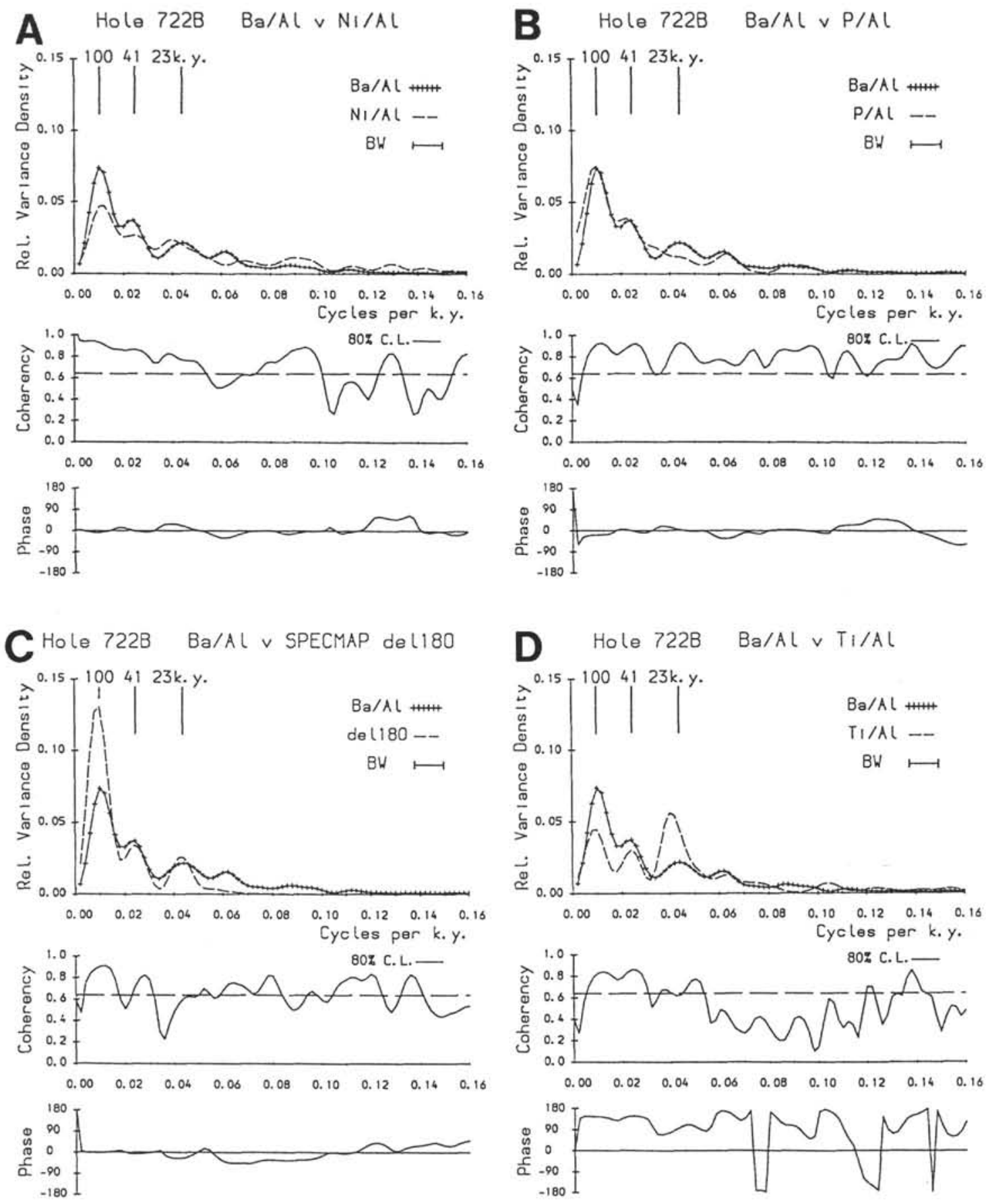

Figure 6. Variance and cross spectra related to productivity $(\mathrm{Ba} / \mathrm{Al}, \mathrm{Ni} / \mathrm{Al}, \mathrm{P} / \mathrm{Al})$ records from Hole $722 \mathrm{~B}$. See text for discussion.

ridge site has permitted investigations into long-term variations in the supply of wind-blown clastics, wind velocity, and productivity.

The input of wind-blown terrigenous matter controlled mass accumulation rates and carbonate contents on the Owen Ridge during the late Pleistocene. Variations in the flux of non-carbonate material are concentrated at the periods of three of the orbital cycles: 100,41 , and $23 \mathrm{k} . y$. with the longest period dominant. There is high coherency and no significant phase difference between ice volumes and carbonate contents at all three orbital periods. The strength of the 100 k.y. signal indicates a link between the wind-blown clastic flux and global ice volumes.
This link was probably continental aridity which determined the availability of dust (see discussion by Clemens and Preil, 1990).

The records of heavy mineral proportions recorded by $\mathrm{Ti} / \mathrm{Al}$ and $\mathrm{Cr} / \mathrm{Al}$ ratios on the Owen Ridge also vary at the three orbital periods, but are dominated by 23 k.y., not 100 k.y., cycles. As shown by others, wind velocity is also dominated by precession cycles partly as a function of the direct link between regional insolation and atmospheric pressure. This correspondence of spectral shapes suggests heavy mineral concentrations were determined by wind strength. The $\mathrm{Ti} / \mathrm{Al}$ record is coherent and in phase with $\% \mathrm{CaCO}_{3}$ and thus aridity at all three frequencies. Thus aridity appears to have determined the timing of heavy 

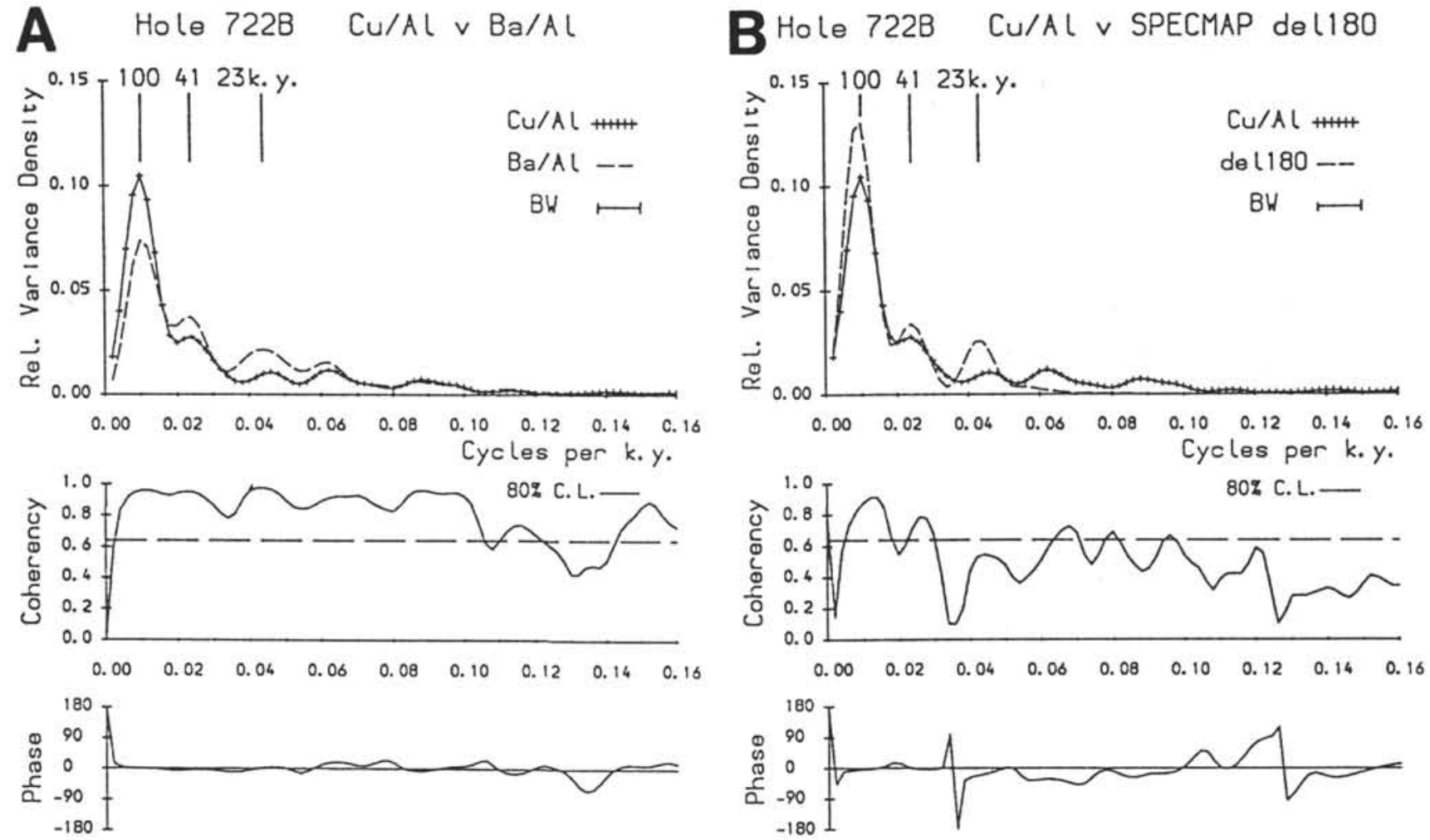

$-1801$

Figure 7. Variance and cross spectra related to the bottom water/sediment redox state $(\mathrm{Cu} / \mathrm{Al})$ record from Hole $722 \mathrm{~B}$. See text for discussion.

mineral deflation. The dominance of 23 k.y. variations indicates that wind speed, and not the availability of dust, controlled the proportion of heavy minerals transported to the Owen Ridge. This probably reflects the greater average grain size and density of heavy minerals compared to others.

The records of productivity over the Owen Ridge $(\mathrm{Ba} / \mathrm{Al}, \mathrm{P} /$ $\mathrm{Al}, \mathrm{Ni} / \mathrm{Al})$ and of bottom water/sediment redox state $(\mathrm{Cu} / \mathrm{Al})$ are distinct from those of wind velocity, and thus upwelling intensity. Again the three orbital periods dominate changes in productivity, but the $100 \mathrm{k} . \mathrm{y}$. variations are most important. Productivity variations are coherent with ice volume variations only at the 100 and 41 k.y. periods. However, they are highly coherent with $\% \mathrm{CaCO}_{3}$ at all three orbital periods and in phase at the longer two. Consequently productivity is linked to aridity and not wind strength at the 100 and 41 k.y. periods. We suggest that this is best explained by productivity controlled by nutrients delivered by runoff. However, at the precession period, productivity lags carbonate by about 40 or $2.6 \mathrm{k}$.y. Thus at this period another, delayed, source of nutrients, probably from upwelled intermediate water driven by the monsoon winds, was also important.

\section{ACKNOWLEDGMENTS}

Our thanks to Warren Prell and Nobu Niitsuma for allowing us to participate on Leg 117. G.P.W. was supported during the shipboard work by a NERC Research Fellowship and subsequently by a Research Fellowship at Downing College, Cambridge. G.B.S. was supported by NERC Grant GST/02/315 as part of the ODP Special Topic initiative. Nick McCave (Cambridge) and Steve Clemens (Brown University) contributed valuable discussion. Finally we would like to record our appreciation to Steve Mowbray for his analytical help in Edinburgh.

\section{REFERENCES}

Boyle, E. A., 1983. Chemical accumulation variations under the Peru Current during the past 130,000 years. J. Geophys. Res., 88:76677680.

Clemens, S. C., and Prell, W. L., 1990. Late Pleistocene variability of Arabian Sea summer-monsoon winds and dust source-area aridity: an eolian record from the lithogenic component of deep-sea sediments. Paleoceanography, 5:109:145.

Dalfes, H. N., Schneider, S. H., and Thomson, S. L., 1984. Effects of bioturbation on climatic spectra deduced from deep sea cores. In Berger, A., Imbrie, J., Hays, J., Kukla, G., and Saltzman, B. (Eds.), Milankovitch and Climate (Pt. 1): Dordrecht (D. Reidel), 181-192.

Duplessy, J.-C., and Shackleton, N. J., 1985. Response of global deepwater circulation to Earth's climatic change 135,000-107,000 years ago. Nature, 316:500-507.

Duplessy, J.-C., Shackleton, N. J., Matthews, R. K., Prell, Ruddiman, W. F., Caralp, M. and Hendy, C. H., $1984 .{ }^{13} \mathrm{C}$ record of benthic foraminifera in the last interglacial ocean: implications for the carbon cycle and the global deep water circulation. Quat. Res., 21:225-243,

Imbrie, J., Hays, J. D., Martinson, D. G., McIntyre, A., Mix, A. C., Morley, J. J., Pisias, N. G., Prell, W. L., and Shackleton, N. J., 1984. The orbital theory of Pleistocene climate: support from a revised chronology of the marine $\delta^{18} \mathrm{O}$ record. In Berger, A., Imbrie, J., Hays, J., Kukla, G., and Saltzman, B. (Eds.), Milankovitch and Climate (Pt. 1): Dordrecht (D. Reidel), 269-305.

Jenkins, G. M., and Watts, D. G., 1968. Spectral Analysis and Its Applications: San Francisco (Holden-Day).

Kallel, N., Labeyrie, L. D., Juillet-Leclerc, A., and Duplessy, J. C. 1988. A deep hydrological front between intermediate and deep-water masses in the glacial Indian Ocean. Nature, 333:651-655.

Prell, W. L., 1984. Monsoonal climate of the Arabian Sea during the late Quaternary: a response to changing solar radiation. In Berger, A. L., Imbrie, J., Hays, J., Kukla, G., and Saltzman, B. (Eds.). Milankovitch and Climate (Pt. 1): Dordrecht (D. Reidel), 349-366.

Prell, W. L., and Kutzbach, J. E., 1987. Monsoon variability over the past 150,000 years. J. Geophys. Res., 92:8411-8425. 
Prell, W. L., Niitsuma, N., et al., 1989. Proc. ODP, Init. Repts., 117: College Station, TX (Ocean Drilling Program).

Prell, W. L., and Van Campo, E., 1986. Coherent response of Arabian Sea upwelling and pollen transport to late Quaternary monsoonal winds. Nature, 323:526-528.

Priestley, M. B., 1981. Spectral Analysis and Time Series: London (Academic Press).

Rossignol-Strick, 1983. African monsoons, an immediate climate response to orbital insolation. Nature, 304:46-49.

Shimmield, G. B., Price, N. B., and Pedersen, T. F., 1990. The influence of hydrography, bathymetry, and productivity on sediment type and composition from the Oman margin and the northwest Arabian Sea. In Robertson, A.H.F., Searle, M. P., and Ries, A. C. (Eds.), The Geology and Tectonics of the Oman Region. Spec. Publ. Geol. Soc. Am., 49:761-771.
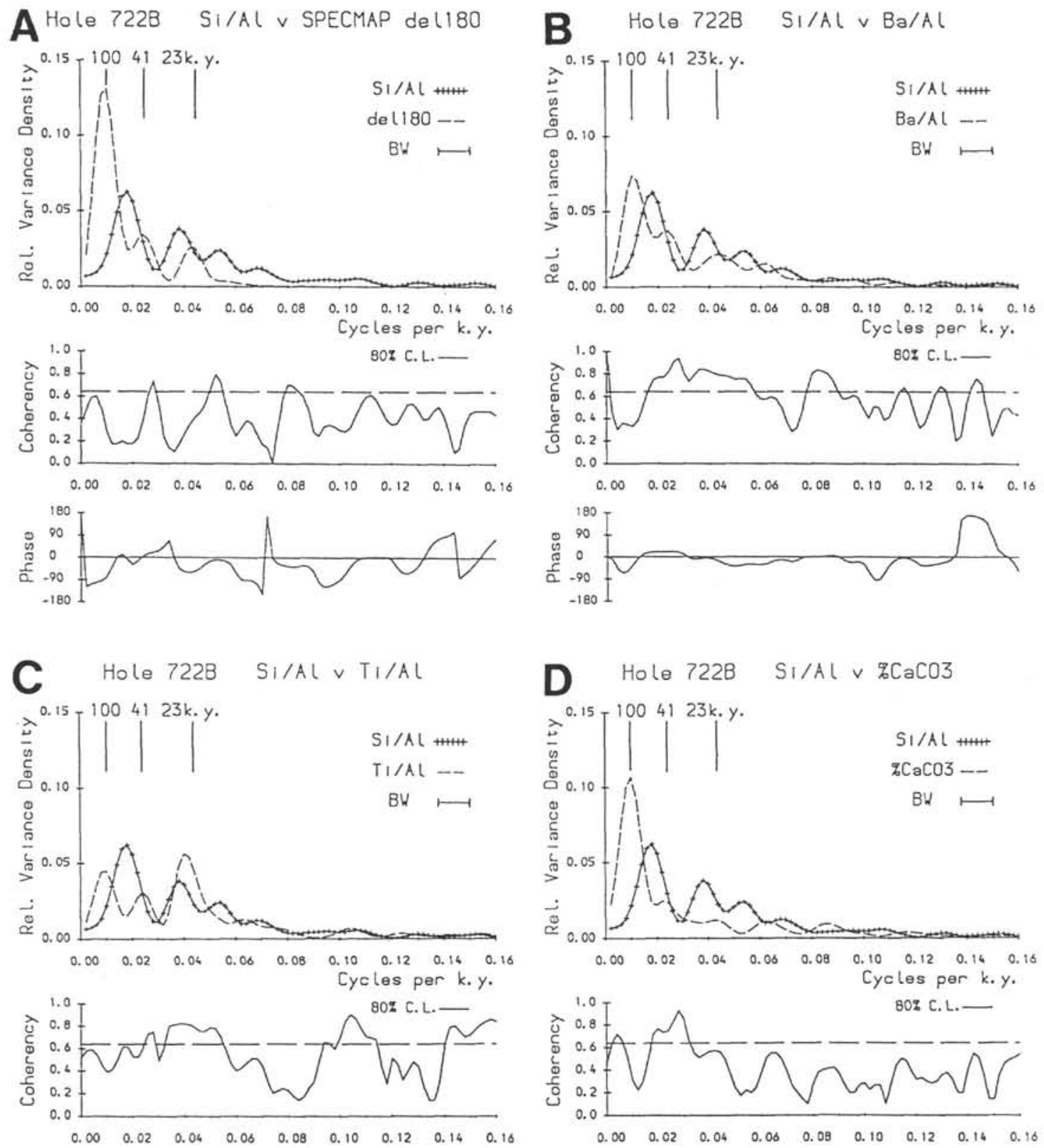

\section{Date of initial receipt: 9 November 1989 Date of acceptance: 25 July 1990 Ms 117B-171}
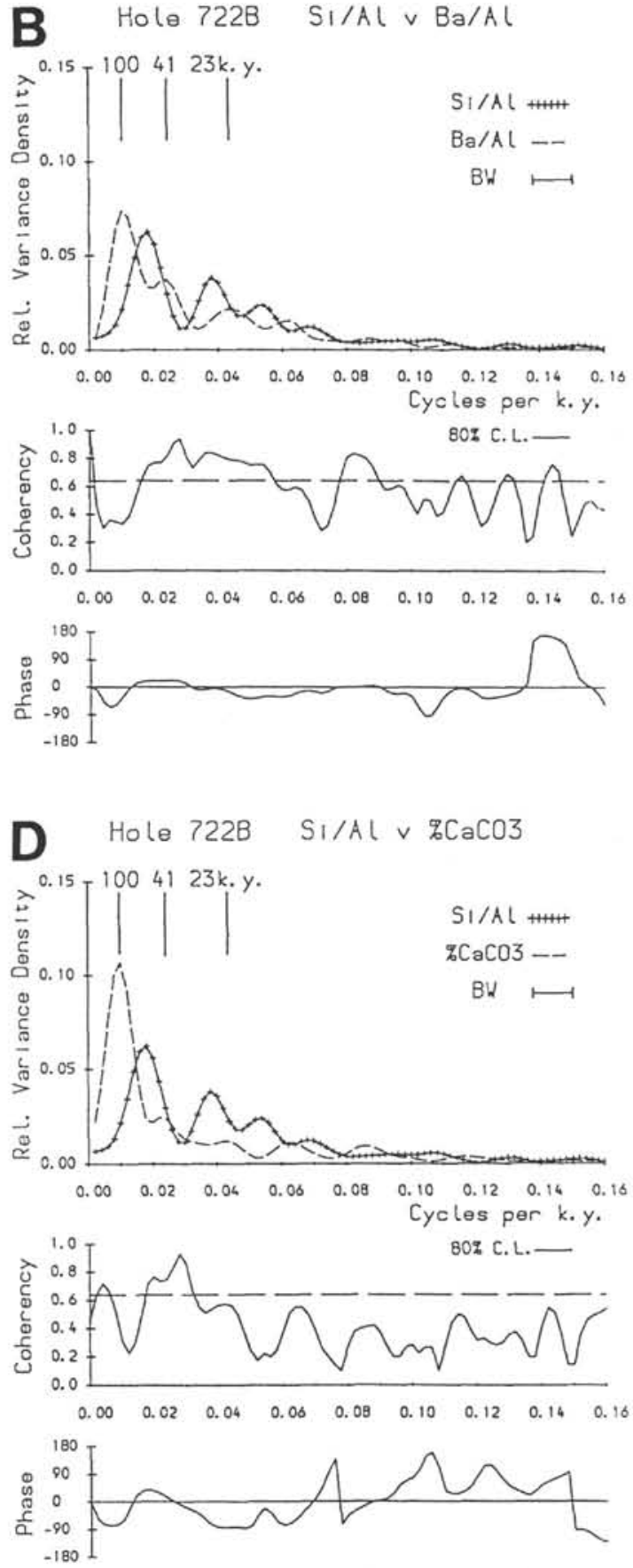

Figure 8. Variance and cross spectra related to silicon ( $\mathrm{Si} / \mathrm{Al})$ records from Hole $722 \mathrm{~B}$. See text for discussion. 


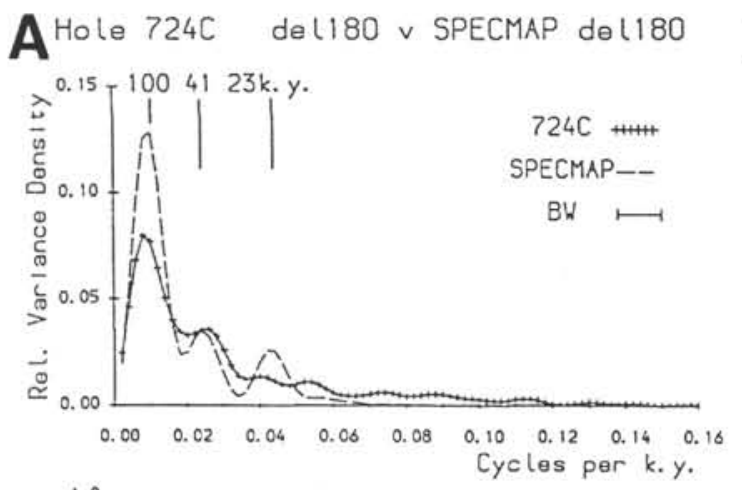

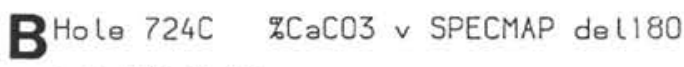
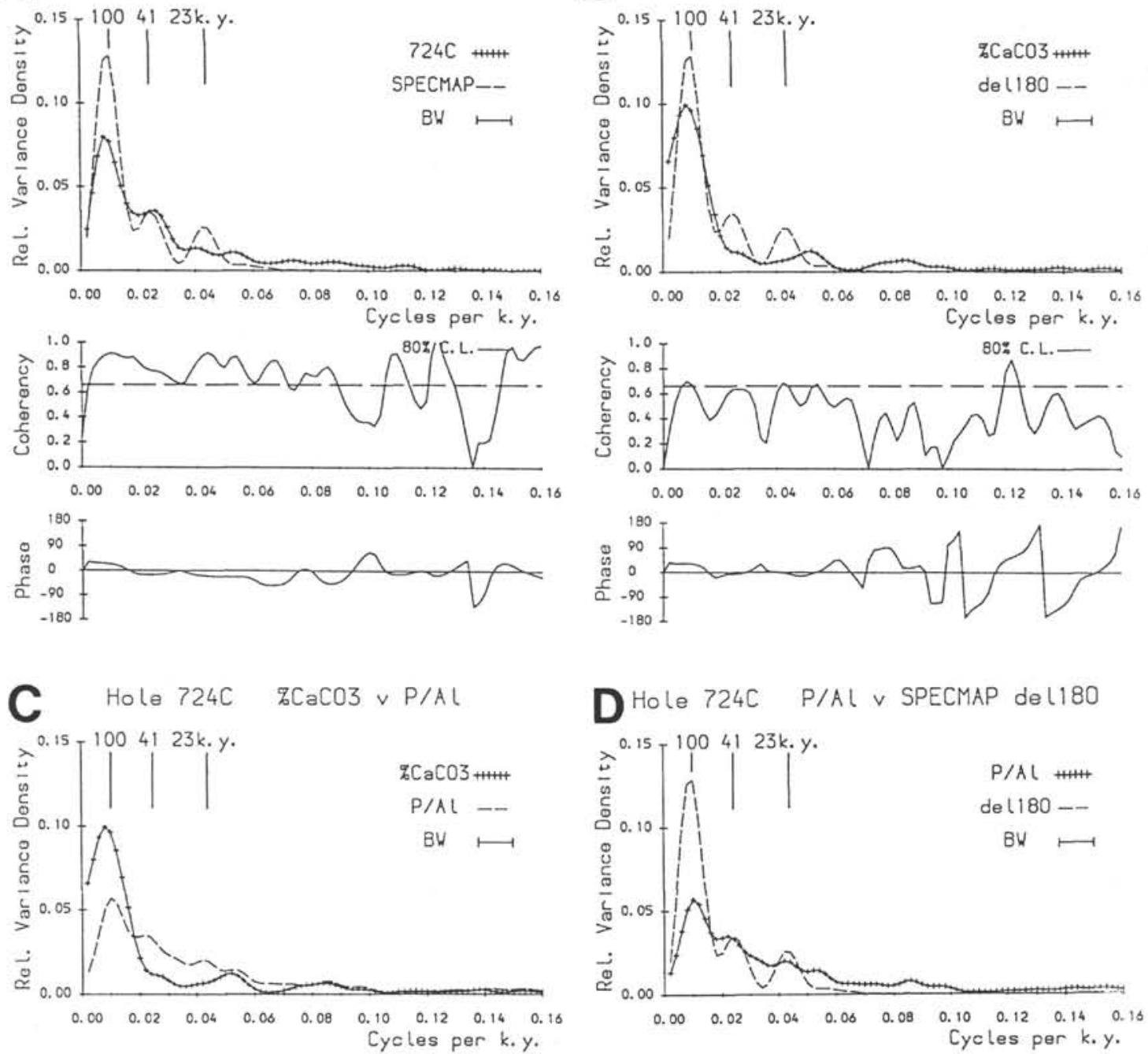

D Hole 724C P/Al v SPECMAP dell180
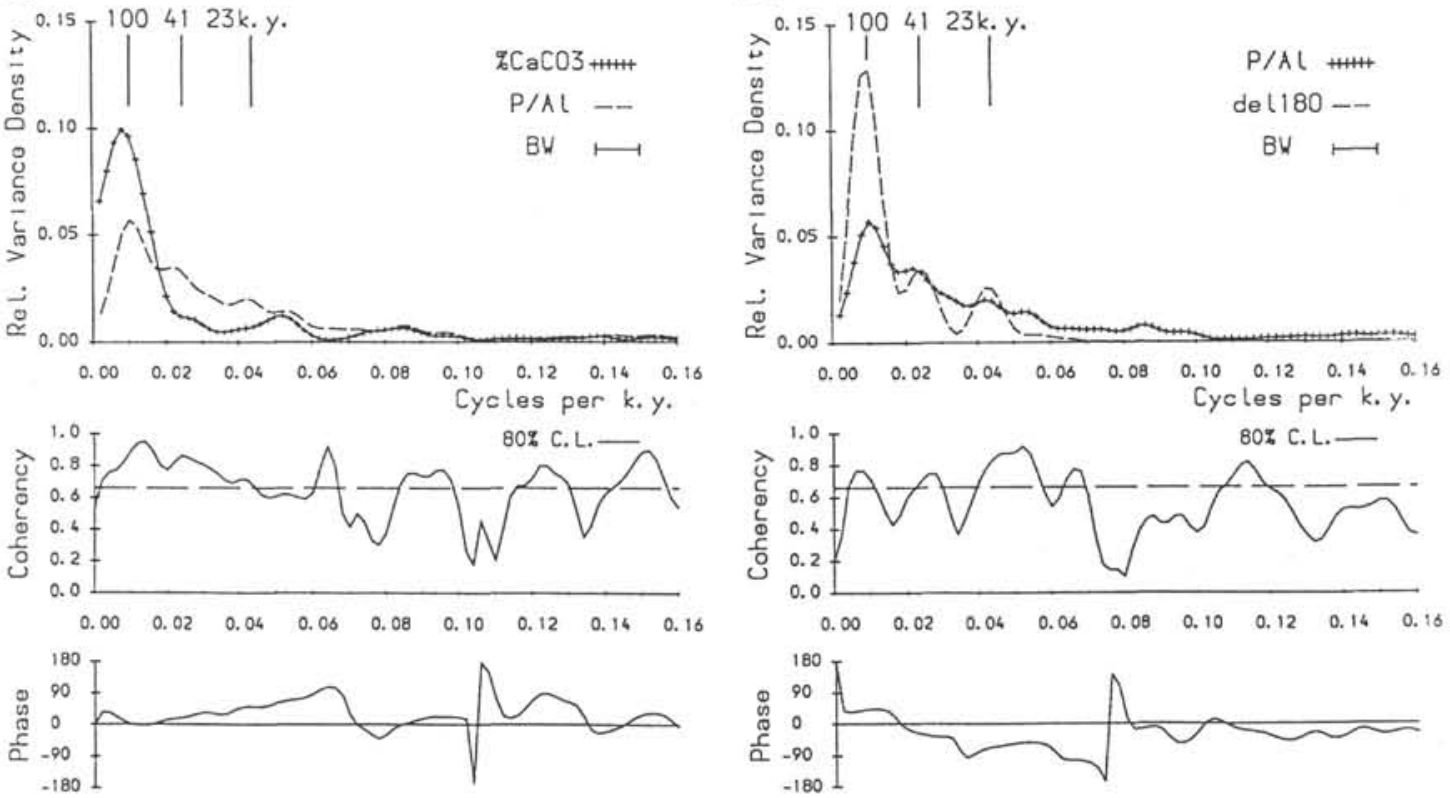

Figure 9. Variance and cross spectra related to $\delta^{18} \mathrm{O}, \% \mathrm{CaCO}_{3}$, and $\mathrm{P} / \mathrm{Al}$ from Hole $724 \mathrm{C}$. See text for discussion. 


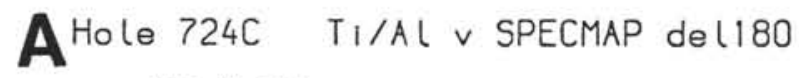
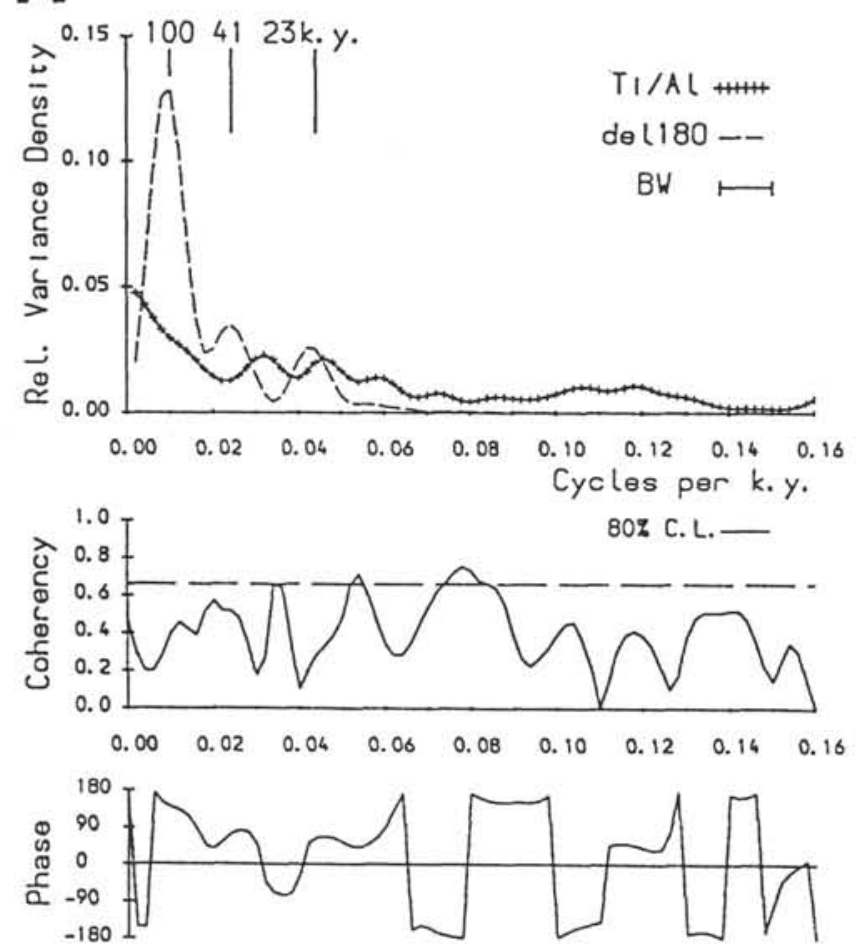

$\mathbf{B}^{\text {Hole } 724 \mathrm{C} \text { SI/AL } ~}$ SPECMAP dell 180
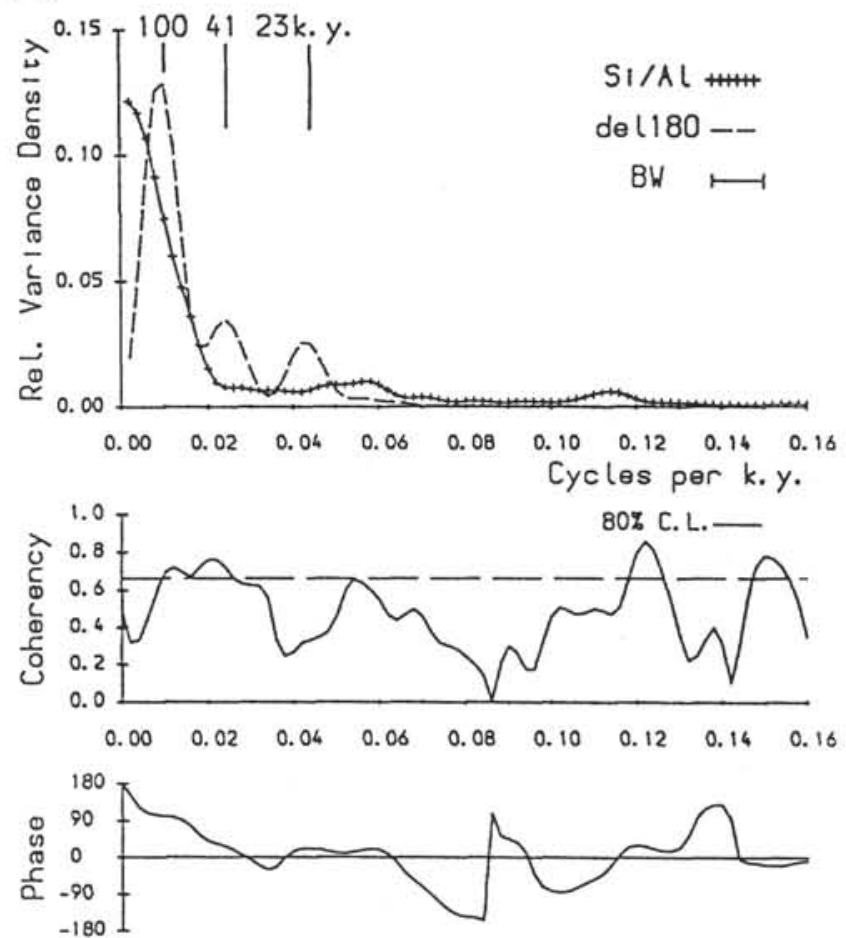

Figure 10. Variance and cross spectra related to heavy mineral (Ti/Al) and silicon ( $\mathrm{Si} / \mathrm{Al})$ records from Hole $724 \mathrm{C}$. See text for discussion.

Table 2. Cross spectral results from Hole 724C. Significant coherency values ( $80 \%$ level) exceed 0.66 .

\begin{tabular}{lrcr}
\hline Parameters & Period/k.y. & Coherency & Phase/degrees \\
\hline$\delta^{18} \mathrm{O}$ v SPECMAP $\delta^{18} \mathrm{O}$ & 100 & 0.91 & $+23^{\circ} \pm 19^{\circ}$ \\
& 41 & 0.78 & $-14^{\circ} \pm 29^{\circ}$ \\
& 23 & 0.92 & $-21^{\circ} \pm 18^{\circ}$ \\
$\mathrm{CCaCO}_{3}$ v SPECMAP $\delta^{18} \mathrm{O}$ & 100 & 0.67 & $+32^{\circ} \pm 37^{\circ}$ \\
& 41 & 0.63 & $-7^{\circ} \pm 40^{\circ}$ \\
$\% \mathrm{CaCO}_{3}$ v P/Al & 23 & 0.66 & $-6^{\circ} \pm 38^{\circ}$ \\
& 100 & 0.89 & $+1^{\circ} \pm 20^{\circ}$ \\
P/Al v SPECMAP $\delta^{18} \mathrm{O}$ & 41 & 0.87 & $+19^{\circ} \pm 22^{\circ}$ \\
& 23 & 0.67 & $+51^{\circ} \pm 37^{\circ}$ \\
Ti/Al v SPECMAP $\delta^{18} \mathrm{O}$ & 100 & 0.51 & $+43^{\circ} \pm 49^{\circ}$ \\
& 41 & 0.50 & $-31^{\circ} \pm 50^{\circ}$ \\
Si/Al v SPECMAP $\delta^{18} \mathrm{O}$ & 23 & 0.70 & $-65^{\circ} \pm 35^{\circ}$ \\
& 100 & 0.40 & $+139^{\circ} \pm 58^{\circ}$ \\
& 41 & 0.52 & $+75^{\circ} \pm 48^{\circ}$ \\
& 23 & 0.28 & $+65^{\circ} \pm 66^{\circ}$ \\
& 100 & 0.69 & $+12^{\circ} \pm 35^{\circ}$ \\
& 41 & 0.72 & $+27^{\circ} \pm 33^{\circ}$ \\
& 23 & 0.33 & $+22^{\circ} \pm 63^{\circ}$ \\
\hline
\end{tabular}

Table 3. Cross spectral results from comparison of Holes $722 B$ and 724C. Significant coherency values $(80 \%$ level) exceed 0.66 .

\begin{tabular}{lccr}
\hline Parameter & Period/k.y. & Coherency & Phase/degrees \\
\hline$\% \mathrm{CaCO}_{3}$ & 100 & 0.51 & $-36^{\circ} \pm 49^{\circ}$ \\
& 41 & 0.63 & $+49^{\circ} \pm 40^{\circ}$ \\
& 23 & 0.73 & $-11^{\circ} \pm 32^{\circ}$ \\
$\mathrm{P} / \mathrm{Al}$ & 100 & 0.63 & $-38^{\circ} \pm 40^{\circ}$ \\
& 41 & 0.85 & $+47^{\circ} \pm 23^{\circ}$ \\
& 23 & 0.50 & $-5^{\circ} \pm 50^{\circ}$ \\
$\mathrm{Ti} / \mathrm{Al}$ & 100 & 0.39 & $+31^{\circ} \pm 58^{\circ}$ \\
& 41 & 0.68 & $+98^{\circ} \pm 36^{\circ}$ \\
& 23 & 0.14 & $-18^{\circ} \pm 77^{\circ}$ \\
$\mathrm{Si} / \mathrm{Al}$ & 100 & 0.22 & $+102^{\circ} \pm 71^{\circ}$ \\
& 41 & 0.44 & $-96^{\circ} \pm 54^{\circ}$ \\
& 23 & 0.51 & $-20^{\circ} \pm 49^{\circ}$ \\
\hline
\end{tabular}



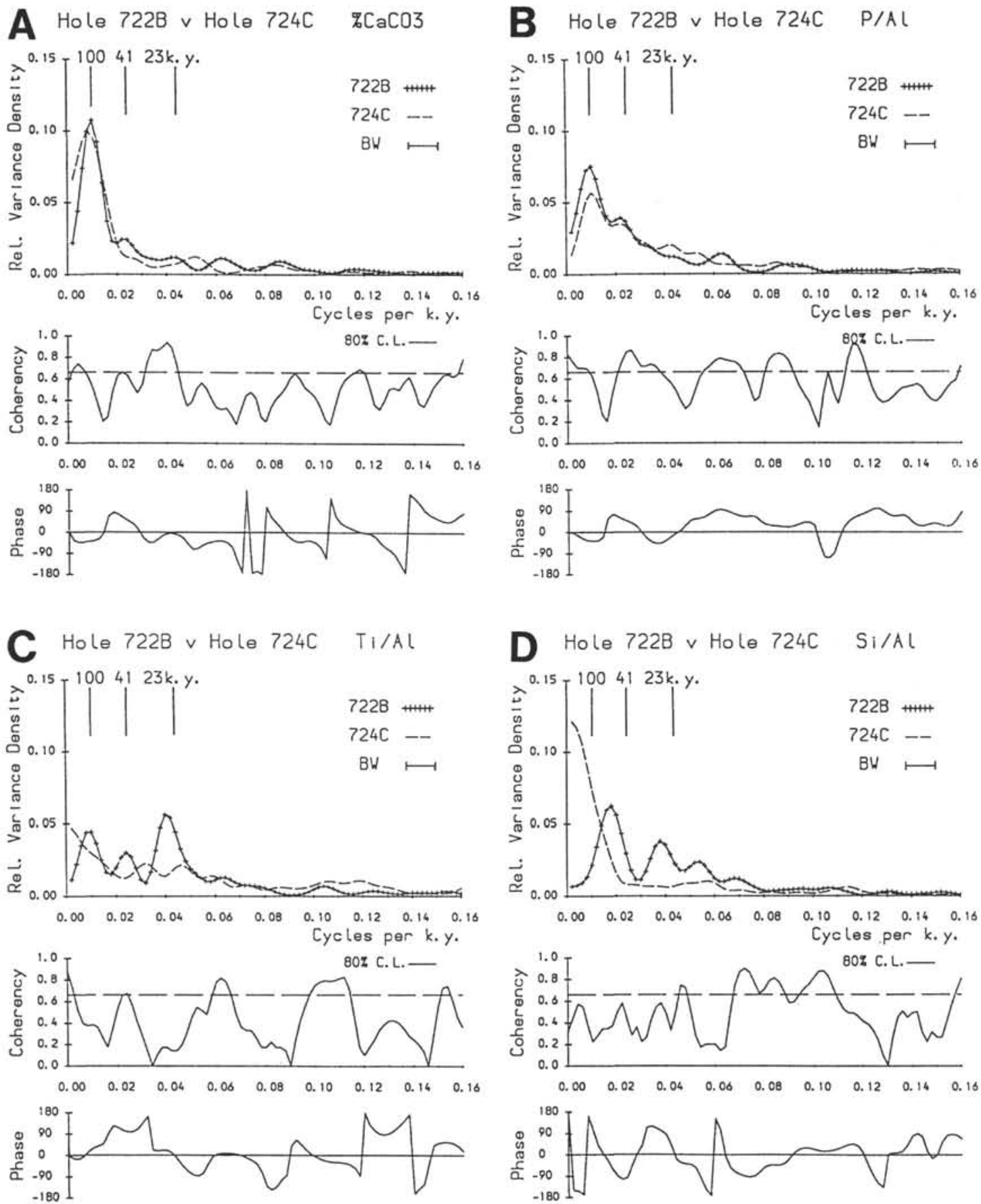

Figure 11. Variance and cross spectra related to comparison of various parameters between Holes $722 \mathrm{~B}$ and $724 \mathrm{C}$. See text for discussion. 